December 2011

\title{
Genocide Studies: An Australian Perspective
}

Colin Tatz

Follow this and additional works at: https://digitalcommons.usf.edu/gsp

\section{Recommended Citation}

Tatz, Colin (2011) "Genocide Studies: An Australian Perspective," Genocide Studies and Prevention: An International Journal: Vol. 6: Iss. 3: Article 5.

Available at: https://digitalcommons.usf.edu/gsp/vol6/iss3/5

This Articles is brought to you for free and open access by the Open Access Journals at Digital Commons @ University of South Florida. It has been accepted for inclusion in Genocide Studies and Prevention: An International Journal by an authorized editor of Digital Commons @ University of South Florida. For more information, please contact digitalcommons@usf.edu. 


\title{
Genocide Studies: An Australian Perspective
}

\section{Colin Tatz Australian Institute for Holocaust and Genocide Studies}

\begin{abstract}
The burgeoning field of genocide studies is faced with several concerns. Foremost is the challenge of finding a space for encompassing and embracing the Holocaust with some comfort. The Judeocide is an ally, not an enemy, and not on the margins. Our maturing discipline needs to find a sense of collegiality, consensus on terminology, and yardsticks with which to measure scales, dimensions, and degrees of the crime. Several other themes also need attention: wider perspectives on the prerequisites of genocide, starvation as a genocidal weapon, a clear separation between motive and intent, genocide by omission, the elusive concepts of "worthy" and "unworthy" victims, the vexed question of why nations and people want or do not want to intervene in the case of endangered peoples, the race factor in all genocides, the educative value of trials, and, a topic least addressed, the complicity of populations whose leaders are the perpetrators.
\end{abstract}

Key words: Judeocide, genocide terminology, genocidal starvation, motive and intent, genocide by omission, victims, race

The growth of our field is impressive. Scholarship spans the alphabet, from the Armenian and Bangladesh genocides to those perpetrated in the former Yugoslavia and in Zimbabwe. Definitional, theoretical, and conceptual issues are addressed, analyzed, aired, and argued. There are two international associations-the International Association of Genocide Scholars (IAGS) and the International Network of Genocide Scholars (INoGS)_albeit at some loggerheads while still talking about a merger. There are two quality refereed journals-Genocide Studies and Prevention: An International Journal (IAGS) and the Journal of Genocide Research (INoGS)-in addition to the admirable and quintessentially Holocaust-oriented Holocaust and Genocide Studies. We have abundant Web sites, prevention and intervention forums, biennial conferences in the United States and abroad, a proliferation of studies in universities and high schools, two major encyclopedias, volumes of annotated bibliographies, eyewitness accounts, curriculum designs, e-mail discussion lists, and vigorous doctoral scholarship. There is also a modicum of advocacy, and resolutions of protest.

Advocacy warrants brief mention. I recall the nonsense of Brewton Berry's insistence that his textbook on race and ethnic relations would view the subject with the same detachment with which a zoologist looks at kangaroos and the same dispassion with which a paleontologist examines fossils. ${ }^{1}$ There is no neutrality and no disinterest in what we study, and there can be no view among us that is pro-genocide. Often the subject matter, and certainly the accompanying denialism, makes us all advocates to varying degrees, establishing, arguing, and sustaining a case.

The fissure rather than fracture between IAGS and INoGS that began to surface in 2005-essentially over what was said to be the American-centric membership of IAGS-arose much earlier in the life of genocide studies than in the long-established disciplines of history, political science, anthropology, and sociology. The latter group

Colin Tatz, "Genocide Studies: An Australian Perspective." Genocide Studies and Prevention 6, 3 (December 2011): 231-244. (C) 2011 Genocide Studies and Prevention. doi:10.3138/gsp.6.3.231 
experienced a few schisms about direction or philosophy or methodology, exhibited paroxysms of self-examination and self-doubt, debated their validity as art or science, science hard or soft, orthodox or radical, applied or "pure," relevant or passé. All took years, even decades, to settle down; we will do this much sooner, and with better grace.

\section{Shadows}

The "disunion" between Holocaust and genocide studies is neither in the past tense nor irrelevant. There is a quite visible separation of the two, hardly self-evident or self-explanatory to the next generation of scholars. Some may dispute this state of affairs, but the chapters and the verses are highly visible.

By the 1970s, Randolph Braham, Harry Cargas, Jacob Robinson, Yehuda Bauer, and Philip Friedman had published, severally and in some cases jointly, comprehensive listings of Jewish life leading up to and including the Holocaust. By the 1980s, Holocaust study was substantial enough for David Szonyi to marshal the essential materials into a comprehensive bibliographical resource guide. ${ }^{2}$ In the shadow of that Himalayan range of material, genocide studies was gestating, with impetus from Leo Kuper's broader Genocide in $1981 .^{3}$ Prior to that germinal overview of the twentieth century, we had important books and documents on the Armenian Genocide, several major volumes on Stalin's "Great Terror," and papers on Bangladesh, Burundi, Indonesia, Nigeria, Paraguay, Sudan, Uganda, and Ukraine. Seldom mentioned, though, was (and is) Yvan van Garsse's Bibliography of Genocide, Crimes against Humanity and War Crimes, published in Belgium in $1970 .{ }^{4}$ Within a short time, Richard Hovannisian published an annotated bibliography on the Armenian genocide and Israel Charny produced a critical bibliographic review, an essential tool that Samuel Totten has extended to eight comprehensive volumes. ${ }^{5}$

Holocaust literature is vast. Profound and meticulous histories deal with its antecedents and descendants, painting huge canvases of the mass destruction of European Jewry. Broad and specialized studies cover topics as varied as the baleful influence of Richard Wagner and the misuse of Friedrich Nietzsche, the nature of Nazi ideology, the Nazi state, the SS, the T4 euthanasia program, the bureaucracy of trains and their timetables, the Einsatzgruppen and their record-keeping, Judenräte (Jewish councils), camp life, medical experiments, rescue attempts, resistance, the role of the churches, Nuremberg and the thousands of trials that followed, the righteous among the nations, memoirs, survivor trauma, and post-event memorials and museums. The big pictures are there, and we are now at a stage where a doyen like Yehuda Bauer can reflect on and rethink the Holocaust. ${ }^{6}$ A student would be hard put to find something really new, unless it were in an unexpected Vatican or similar archive, or an aspect requiring intense micro focus.

Genocide studies has yet to achieve that kind of exhaustive and overarching state. Since World War II especially, most disciplines have engaged in increasingly narrow specialization; genocide studies has perforce become increasingly holistic, much more generalist than specialist. Of necessity, it needs lenses ranging from accountancy, administration, and architecture through biology, chemistry, and engineering to medicine, philosophy, politics, psychiatry, psychology, religion, social and physical anthropology, sociology, and zoology. One, or two, or ten scholars cannot surmount a genocide case study in this way, though a few seem to want to do so. Attempts at an Everestian view of a case must be collegial, built on aggregations of study. The templates and tools of Holocaust analyses are there, and genocide scholars 
cannot ignore, avoid, or abjure them, as a few seem inclined to do. Single-author overviews have begun with Ben Kiernan's bravura and commendable history of genocide and extermination from Sparta to Darfur. ${ }^{7}$

Dichotomy is perhaps too strong a word, but a cleft between Holocaust and genocide studies is apparent in both conference agendas and journal content. Few genocide scholars have attended the eleven biennial Lessons and Legacies conferences run by the Holocaust Education Foundation since 1989, and few Holocaust historians have presented at the eight IAGS biennial events held since 1995. Holocaust and Genocide Studies began publishing in January 1986, and between then and spring 2011 it published some 349 articles. Despite the journal's title, only thirty-seven itemssome $10.6 \%$ of all contributions-focus on either comparative genocide theory or specific cases of genocide other than the Holocaust. Genocide Studies and Prevention, born in July 2006, has a less balanced portrayal of cases: by my count, only five of 102 articles, or just under 5\%, can be seen as Holocaust focused. The Journal of Genocide Research, launched in 1996, has published just over 250 articles to date, of which some $22 \%$ are Holocaust related or centered. Some imbalance is clearly evident, but the question is why. How do we explain this inclination to stand alone or (largely) stand aloof, and should a dedicated symposium examine the issue?

\section{Language and Subdivisions}

No sooner has genocide studies come close to coherence than a peculiar splintering has occurred. "Genocide" has taken some sixty years to become indelibly part of the political and social lexicon. Yet within the past decade we have all manner of subdivisions, giving an impression that we have discovered a new species of behavior or a new crime. Scholars use words like democide, ethnocide, faminocide, feminocide, gendercide, linguicide, omnicide, econocide, and politicide, seemingly intent on aggrandizing the suffix to draw attention to the seriousness of their subject matter.

Do we need such proliferation? Does such specialization suggest new academic appointments or new journals in these ostensibly discrete fields? English is often deficient. For example, some commonly used terms such as racism and anti-Semitism are flat words that can convey anything along a spectrum ranging from the plain silly to the fatal. Each needs an extra word to modify or qualify the subsequent noun. So too the matter of genocide. Surely we can get by with adjectives-ethnic genocide, political genocide, famine genocide?

Norman Naimark rightly points to the reality that ethnic cleansing "bleeds into genocide." 8 Can we ever say that ethnic cleansing never results in genocide? No-so why keep using that term? Is it considered a softer one, implying a lesser crime? Language has always assailed the history of Jews. The term "holocaust," from the Greek holokauston and in lower case, was first used by J. Castell Hopkins (1896) and Marion Harland (1897) to describe the "Mahometan cruelty" of Sultan Hamid II in the context of the Armenian massacres.9 "Holocaust," with a capital H, was Elie Wiesel's chosen term because he wanted the Jewish destruction to be tied to God (the word derives from a sacrificial offering wholly burned by fire in exaltation of God). Arno Mayer has called it a "religiously freighted word concept."10 The Hebrew words for "catastrophe" and "destruction," shoah and churban, suggest a more human, secular realm of death, and rightly so. There was no Jewish ritual or offering, as in Abraham's binding of Isaac. No angel of mercy intervened on God's behalf to offer an alternative sacrificial body. There was only the total, systematic annihilation of the Jewish collective existence. That, says Arno Mayer, was 
Judeocide ${ }^{11}$ - a more pointed and pertinent term, despite my critical comments above about the surfeit of "-cides."

\section{Definitions, Typologies, and Categories}

We have been saddled with a deficient definition of the crime since 1948; efforts to rectify it have come from, among others, Raphael Lemkin, Pieter Drost, Irving Louis Horowitz, Henry Huttenbach, Steven Katz, Helen Fein, Frank Chalk and Kurt Jonassohn, Jennifer Balint and Israel Charny, Levon Chorbajian, and Ward Churchill to no avail. The 1998 draft of the (2002) Rome Statute on the International Criminal Court adopted verbatim the 1948 Convention on the Prevention and Punishment of the Crime of Genocide (UNCG). ${ }^{12}$ I asked an American delegate to Rome why this impaired definition was left intact. Opening the discussion, she explained, had led several major power delegations to state bluntly enough that should the definition be revised and possibly broadened, they would not ratify it. Hardly a surprise-but we will now have to live with the present wording for perhaps the next half-century. What will it take to bring about an acceptable rethink? Chipping away by academics may not be the answer.

Scientists thrive on systematic classifications of types that have common characteristics. We are not botanists or geologists, and we don't need the "clarity" and certainty of definition that some scholars seek. A rough sketch or guide is enough to enable one to locate a domain, decide on an area to pursue, set limits on time and place, and minimize grotesque comparisons. What is useful is not so much finding echoes and analogies from a few cases but analyzing similarities and differences in relatively similar contexts to arrive at the essences involved. Chasing down Australia's genocide through Holocaust prisms is hardly a useful or fruitful exercise.

Lemkin provided a typology based on some forty cases, ranging from Carthage to the Holocaust, in his as yet unpublished History of Genocide. Frank Chalk and Kurt Jonassohn provide a useful perspective on motivation: to terrorize or eliminate a real or potential threat, to acquire wealth, or to implement an ideology. ${ }^{13}$ Helen Fein offers a sociological perspective that suggests ideological, retributive, developmental, and despotic preconditions for genocide. ${ }^{14}$ Mark Levene gives us a heuristic view of the war contexts of genocide in the age of the nation-state, whereby a state wages war against other states, against states that appear "illegitimate," or against groups within a state that appear "illegitimate." 15 Barbara Harff and Ted Gurr furnish a descriptive and analytical categorization of hegemonic and xenophobic genocides and of retributive, repressive, revolutionary, and hegemonic politicides. ${ }^{16}$ William Rubinstein proposes a time frame that begins with genocide in preliterate societies and proceeds through genocide in pre-modern empires and states (600 BCE-1500 $\mathrm{CE}$ ), colonial genocides (1500-1914), genocide in an age of totalitarianism (19141975), and contemporary "ethnic cleansing" (1945-2002). ${ }^{17}$

These models are but tools for examining problems, especially enduring ones like genocide. They are not laws of social physics. They enable our scholarship-and in that pragmatic sense it may be profitable to consolidate the extant typologies for students. We can do better than such broad labels as the "ancient" or "pre-modern" world when it comes to researching the fates of the Jebuzites, Perrizites, Girgashites, Edomites, Moabites, Ammonites, Canaanites, Hittites, and all those other "-ites" who vanished in what are today Israel, Jordan, and the Sinai Peninsula. And while the Seleucid king Antiochus IV may be pre-modern, there is something to be gained by looking closely at the first serious attempt at Judeocide, in 168 BCE. 
Western civilization has always insisted on rankings-biggest, highest, longest, fastest, richest-in all endeavors. Much effort has gone into assessing genocides as the "biggest," "most unique," and so on. We don't need this kind of competitive comparison. But we do need a model, a genocide Richter Scale, that enables a student to distinguish, however roughly, events that differ so widely in compass, scope, scale, technique, time frame, outcome, accountability, and the ensuing effects on regional and global relations. The case of Australia's treatment of the Aborigines is genocide, but it has hardly any features comparable with, say, the Armenian, Jewish, and Rwandan cases. Some order of magnitude (though hardly a number, as in earthquakes), some general indicators, would be helpful. Criminal law systems often distinguish levels of murder and manslaughter. ${ }^{18}$

\section{Prerequisites for Genocide}

Yehuda Bauer and Richard Dekmejian ${ }^{19}$ have outlined the fundamental ingredients of a genocide. Their wording is a little different, but the essence is that genocide occurs where there is (1) an ancient hatred or an ideological imperative; (2) a war setting, such that things can be done, literally, under a smokescreen; (3) a brutal dictatorship; (4) a compliant bureaucracy; and (5) the use of technology. Neither would claim rigidity for these models, and both would concede that their representation derives from European and Near Eastern experiences in the twentieth century.

Genocide studies allows a wider landscape. Not every case conforms to these useful templates. Some ideological imperatives are not so ancient, as in Burundi, Rwanda, and Darfur. Not all genocides occur in wartime, and in some casesRwanda again-machetes and crystal radio sets represented the most advanced use of technology. Starvation is the most ancient and efficient of techniques, as in German South-West Africa, but is not given the attention it warrants.

The complicity of Western states in genocides is under scrutiny, as noted in an anthology edited by Adam Jones, ${ }^{20}$ but we need much more study of genocide within democratic states. A sharper look at the fate of native peoples in the United States, Canada, Australia, and New Zealand-undertaken by Samuel Totten and Robert Hitchcock in their recent edited volume on the genocide of indigenous peoples ${ }^{21}$-is warranted. Many aspects of Belgian, English, (Wilhelmine) German, Dutch, and French colonial administration also demand scrutiny.

A stark dedication to a totalitarian explanation is shown in Samantha Power's 2002 book A Problem from Hell. ${ }^{22}$ Power describes and analyzes American inertia, lack of political will, absence of morality, and crass expediency when the United States could have acted in several ways to ameliorate, or even halt, the killings of Armenians, Jews, Kurds, Bosnians, and Rwandans. Americans, she insists, must face that history; but she doesn't once mention their practices against Native Americans, nor once refer to Ward Churchill's "little matter of genocide" in the Americas. ${ }^{23}$

The term "genocide" has only recently come into the Australian vocabulary vis-àvis its own nation, causing anger, dismay, and, inevitably, denialism. There has been no desire to look at the physical killings of Aborigines that ended in the late 1920s, or the forcible removal of children that began in the late 1830s and ended in the 1980s. ${ }^{24}$ Denial of this dark history arises from a strong belief that "Australianness" is an inherent prophylactic against, or an antidote to, such bad, homicidal, let alone genocidal, behavior. A recent foreign minister argued that Australia can't possibly breach international treaties on child, sex, and race discrimination because we are Australians. Like their American cousins, Australians regard themselves as a moral people, as decent colonists and quintessential democrats. 


\section{Motive versus Intent}

Several analysts have asked the pertinent question of whether there can be genocide without a special or specific intent to commit that crime. In September 2011, the University of Leicester in England dedicated a conference to genocidal intent and its significance. Airing the issue of intent is timely. We have long been socialized to "motive and means" as prerequisites of criminal acts. Genocide is a crime, a heinous one; intent is the key, not the reason why. It is a reasonable assumption that the 1948 UNCG, emerging as it did from the vortex of World War II, was born out of the conviction that intent to destroy a national, ethnic, racial, or religious group must, by evidence and intuition, be accompanied by male fides, bad faith and evil intent. The UNCG says nothing specific about the nature of intent, and this makes Australian, American, New Zealand, and Canadian defenders of child removal (from allegedly baleful tribal connections) a fascinating area of study. Governments of these states still contend that "good" has come out of these practices and that many removed children have made outstanding contributions as activists, actors, artists, athletes, professionals, and writers. ${ }^{25}$ While the analogy may be a little far-fetched, it echoes here of the controversy surrounding the useful things that arose from Nazi medical experiments. We give a name to such beneficial outcomes as the better understanding of shock and hypothermia: "the fruits of the poisoned tree."

There are some strong legal arguments in Australia that the motivations for this crime are irrelevant. ${ }^{26} \mathrm{~A}$ pertinent legal view is that "it can be (misguidedly) committed 'in the interests' of a protected population." 27 Or, as the moral philosopher Raimond Gaita contends, "the concept of good intention cannot be relativized indefinitely to an agent's perception of it as good." 28 If this were the case, he writes, then we would have to say that Nazi murderers had good but radically benighted intentions, since most of them believed they had a sacred duty to the world to rid the world of the "race" that polluted it.

\section{Omission and Commission}

Most commonly, genocide is a crime of commission. Commonly enough, however, failure to feed people is an efficient way to destroy people. "Hunger as a low technical weapon" is the phrase used by Jonassohn in a 1997 essay; "Famine Crime in International Law" is the title of an analysis by David Marcus published in $2003 .^{29}$ We have major studies of Soviet and Ukraine famines by James Mace, Robert Conquest, and Stephen Wheatcroft, ${ }^{30}$ among others, and several key works on the Irish potato famine by Cormac Ó'Gráda and James Donnelly. ${ }^{31}$ Mace is crystal-clear on the question of the Soviet government's genocidal intent in seizing Ukraine's food production. Yet the works on Ireland and on some African examples (Sudan apart), such as Ethiopia, Malawi, Nigeria, Somalia, and Tanganyika, sometimes lack the genocide studies focus that many would want to see. In classrooms it is easy enough to point students to a genocidal framework, but these case histories sometimes escape the "hook" of genocide with suggestions that they were instances of "something else," some other and less malevolent category, often with an inference that famine is but a "natural disaster." I am not sure whether this is because these authors are not steeped in the genocide studies mode or whether it represents a conscious evasion of the ultimate word in the lexicon. A few years ago I visited the local potato famine museum in Skibbereen, in Ireland's County Cork. A fine building, with much captioning about the blight, Phytophthora infestans, but not about the British; a stove for a remedial soup-kitchen recipe that was worse than the hunger regimen; and images 
of a lot of dead people. Genocide is nowhere mentioned and, it would seem, was never in question.

One hitherto neglected or overlooked aspect of genocide by omission warrants attention: the matter of wanting and not wanting. In social science generally, in history and philosophy, we always look for (usually) complex explanations in ideology, in administrative and organizational behavior, in social physics, in procedure and mechanics, in psychological states of mind, in individual or group behavior, and, all too often, in what we call "grand theory." Sometimes explanations are so simple that we can't bring ourselves to believe that something so plain, so unadorned, can answer the big questions.

We are well versed in the role of bystanders, those whose indifference allows perpetrators to "deal with" victims. We need to look specifically at what Bauer calls "hostile indifference." The 1938 Évian Conference in France purported to deal with the crisis of German Jewry. Of the thirty-two nations present, thirty-one offered some technical explanation for not taking any Jewish immigrants. Australia's delegate, Lieutenant-Colonel T.W. White, said, "It will no doubt be appreciated also that as we have no real racial problems, we are not desirous of importing one...."32 Only the little Dominican Republic said it wanted 100,000 Jews. "Wanted" is misleading-what General Rafael Trujillo wanted was salvation for his sullied reputation-but in the end he took 500.33 And not enough has been written about the attitudes of Churchill and Roosevelt toward Jews in crisis, about their not wanting to take in a clearly imperiled people.

Reams have been written about the bombing of the railway lines to Auschwitzabout the British, who said that, technically, they could not do it so it had to be the Americans, and the Americans, who could not do it because of this, that, and the other. ${ }^{34}$ Sir Martin Gilbert has analyzed the many rationalizations in his Auschwitz and the Allies and his documentary film of the same title. ${ }^{35}$ In the end, the answer is relatively simple: the Allies didn't want to. More reams have been written about Pope Pius XII and his overt inaction. In a recent book, Paul O'Shea asks why this shy and cloistered man, this complex and convoluted man, in so many ways a good man, was so voluble on the Church and so silent on the Jews. Why, when he had the chance, did he agree to mention atrocities in general but not atrocities against Jews and Poles? ${ }^{36}$ The answers are complex, at one level; at another, the key level, the answer is simple: because he didn't want to. He wanted to confront the satanic Communist menace, and he did so with vigor; he didn't want to confront the National Socialists, even though he saw them as thugs. Bill Clinton has admitted that the greatest failure of his presidency was his not wanting to hear the word "genocide" about Rwanda. His underlying reasons may well have been highly complex, but "not wanting" was the phrase he used in an emotional and forthright television interview in Australia a few years ago. ${ }^{37}$ And most churches, mosques, and synagogues don't want to hear, let alone speak out, about genocidal events as they occur. The difficulty, of course, lies in diagnosing the reasons why people don't want to hear, see, intervene, or seek accountability.

One speculative area is the elusive concept of "worthy" and "unworthy" victims. We need to recall historian Saul Friedländer's conclusion that whatever motivated the world's passivity before and during the Holocaust, "it always resulted from a choice in which the Jew was always less than whatever other consideration he was weighed against." 38 Robert Wistrich has given us the most insightful account yet of why this is so in A Lethal Obsession, a massive catalogue raisonné of twenty 
centuries of Jew-hatred. ${ }^{39}$ In the end, Jews don't weigh, or they weigh in the wrong way. So, who weighs what? Who-or, more particularly, what-warrants intervention, military intervention, genuine sanction? Intuitively we know the answer, but who is brave enough to try to capture, document, and sustain a case on the basis of such indefinable and intangible evaluations?

\section{Neglected Articles}

We rail at the defining of genocide in the UNCG, but it remains our only justiciable and actionable yardstick. To lessen any sense of confinement or constraint, we should venture more into the very broad base given by UNCG Articles II (b) and II (c) and the conspiracy, complicity, and attempted genocide set forth in Article III.

Article III of the UNCG is as flawed as Article II. On the face of it, the convention equates what seem like incommensurate acts of genocide-for example, physical killing with forcible removal of children (both hallmarks of Australian genocide). The document does not list the five acts of genocide as co-components leading to the overall destruction of a specific people; each act can be legally construed as a distinct and culpable genocidal activity. Article III makes criminal the seemingly unequal acts of actual genocide and the attempt to do so, conspiracy to do so, and complicity therein. Western criminal law systems always distinguish between an actual crime and the attempt to commit it; the UNCG does not do so. Historian Henry Reynolds insists that while there was a state conspiracy and an attempt to eliminate the Tasmanian Aborigines, the "plot" failed and thus no genocide occurred. ${ }^{40}$ Lack of fruition or completion of intent is not a negation of genocide. Article III is explicit, and scholars could well pay more heed to cases like this one.

Australia is a strong case for a wider approach. Lemkin's draft chapter on Tasmania was published posthumously in $2005 .{ }^{41}$ It focuses on the brutal treatment of the remnant people on Flinders Island, on the way in which kidnapping, prostitution, and economic exploitation of women led to an inability to reproduce. Lemkin also saw the stealing of children as a form of genocide. Had he lived to complete his three-volume case study, he might well have found that Australia's answer to the era of physical killing-namely, protection by means of rigidly segregating and isolating Aborigines from their predators-in turn became its own form of genocide. Protectionsegregation, as I have shown elsewhere, ${ }^{42}$ placed Aborigines under special (and often unchallengeable) laws and administrative systems that were outside mainstream institutions; were conducted in secrecy; abnegated what we understand by the concept of "the rule of law"; made Aborigines perpetual wards of the state; deprived them of mainstream social services, welfare benefits, wage awards, and trade-union rights; imprisoned or punished them for offenses that only they could commit; exiled or separated families for indefinite periods; and eroded, outlawed, and often eliminated cultural and social practices.

Lemkin would have judged that this "misguided kindness" (to use his phrase), this incarceration on remote government-run settlements and Christian-run mission stations, led to a systemic "destruction of the essential foundations" of Aboriginal societies, certainly to the "destruction of personal security, liberty, health, dignity, and even the lives of individuals belonging to such groups." ${ }^{3}$ UNCG Articles II (b) and (c) are perhaps too broad, but they offer more scope for study.

The courts are our likeliest avenue out of the UNCG's definitional deficiencies. The Akayesu case in Rwanda-which resulted in a life sentence for rape as an act of genocide-is of the utmost utility. ${ }^{44}$ The tribunal's decision also declared that it 
is possible to deduce a genocidal intent in a particular act from the general context of other culpable acts directed against a particular community-in short, evidence from the circumstances. We always see criminal courts as one response to the génocidaires. Why not civil suits, in which the burden of proof is less but the trial of the issues is just as forensically keen and the outcome just as painful for the defendants? Three descendants of Armenians killed during World War I have now brought civil suit against Turkey for the restoration of, or damages for, parcels of land to which they have deeds, acreages now occupied by Turkish air bases. ${ }^{45}$ Cases like this can be as effective as political resolutions and the flurries of international diplomacy. (The draft report of the Armenian Genocide Reparations Study Group has pointed some of the ways forward using legal, constitutional, and geopolitical arguments. ${ }^{46}$ )

\section{The Matter of Complicity}

Societal complicity in genocidal events is perhaps more painful than the political variety. Merely knowing is a form of complicity; one need not actually do something to be complicit. Few studies have examined the connivance of people. For me, the most startling illustration of the complicity of a populace is Hans Hellmut Kirst's 1968 novel, The Fox of Maulen, in which National Socialism attracts, enthralls, and involves an entire German village except one man-the Fox-who resists.

The Nazi Impact on a German Village (small, rural, mainly Catholic Oberschopfheim in southwest Germany), published in 1993, and What We Knew (analyzing terror, mass murder, and everyday life in Nazi Germany) open up a perspective that most people, including scholars, don't want opened, namely the prospect of having to indict whole nations, societies, or peoples, even if only morally. ${ }^{47} \mathrm{We}$ need much more searching works than Daniel Jonah Goldhagen's overblown portrait of an "eliminationist" Germany. ${ }^{48}$ I believe we have one such work in Peter Fritzsche's Life and Death in the Third Reich, an extraordinary insight into how Germans made deliberate, self-conscious, and knowledgeable political choices during the National Socialist era. 49

Is such community complicity a moral nursery, a necessary preparatory seedbed in which legal-criminal activity can occur later? Yes. And this poses difficulties for those who seek responsibility and accountability in one man (Hitler, Stalin, Pol Pot, Milosevic, Karadzic, al-Bashir), a small coterie of "true believers," a 50,000-strong body such as the SS, a special unit like Eichmann's Bureau IV B 4 (Jewish Affairs and Evacuation), or "only" the civil service.

Genocide scholarship has done well in establishing cases of genocide and, for the most part, in distinguishing that crime from genocidal massacres, mass murder, atrocities, war crimes, and crimes again humanity. We now know a great deal about what occurred in many places, the times and places of those events, the actors and factors involved, and the motives, or ostensible motives, for their behavior. We now know much about how genocide is committed by states ideologically, politically, economically, militarily, and technically, but we know little about how genocide is humanly possible.

How is genocide possible at the individual level? Holocaust analysis has attempted to address this question, but has not arrived at any really satisfactory answer. Bureaucracy is one answer, as Raul Hilberg insisted in his many volumes. ${ }^{50}$ While bureaucracy almost always displaces the moral responsibility of its individual operatives, we all remain curious about the "transmission belts" that drive men and women in these events. The common ground seems to be one or more of such forces 
as demonizing a victim group, dehumanizing them, "insectifying" them, obeying authority, and, more latterly, Christopher Browning's compelling case of "conforming,"51 though this is one that derives from the insights of social psychology and the experiments of Stanley Milgram. Psychologist James Waller has addressed "how ordinary people commit genocide and mass killing." He rightly leaves us with the "painful recognition that the persistence of inhumanity in human affairs is incontrovertible," yet he has some optimism about prevention, intervention, and punishment. ${ }^{52}$

Of all the strategies to defeat both group and individual evil-doing, Waller sees education as having "substantial humanizing effects" as an "antidote to our collective inhumanity." 53 Scholars always see (and always want to see) education as the answer to the unreasonable and the irrational, as the way to get to the hearts and minds of would-be evildoers. As a long-time student of race relations, I can only conclude that the educational route has never been able to deliver the results expected of it. But there is evidence enough that where racial incitement and overt vilification are dealt with by criminal sanction, rather than treated as social diseases that require "therapy" and "counseling," some demonstrable deterrence occurs. Penalty (and all else) cannot stop the mindset, but it is often the only way to stop the overt act necessary to commit the crime.

\section{Much Else}

The race factor is too often avoided, downplayed, or oversimplified in case studies. It is true that there are no "races," as in the "science" of nineteenth- and twentiethcentury anatomy and physical anthropology, but there certainly is racism. Race-ism is but shorthand for any set of beliefs, real or imagined, that the anatomy, color, clan, geography, history, language, or religion of "others" produces ineradicable and undesirable social characteristics and that such beliefs justify acting against the defined groups. In this sense, nearly all genocides will have a "race" factor. We need more precision when talking about victim groups, avoiding such overly broad sweeps as "Africans," "blacks," "Native Americans," and so on. And "ethnic conflict" is not a sui generis category of thinking and acting, one that doesn't involve "race." We still have no definite conclusion about the real basis of the Armenian Genocide: Racist in the narrow sense? Religious? Linguistic? Chauvinistic?

We would do well to look again at the meaning of resistance. Movies give us stereotypical visions of the French Maquis blowing up railways and garroting gray guards. Resistance to genocide takes many forms. Sheer survival is one form, and at Yad Vashem - the Holocaust Martyrs' and Heroes' Remembrance Authority in Jerusalem-we are taught that survival was more a matter of luck than of any other phenomenon. We need some comparative studies, more on active versus passive resistance, and more analyses like Keith Watenpaugh's assessment of the League of Nations and Armenian rescue. ${ }^{54}$

Impunity for perpetrators gets less attention than it warrants. Even if we traverse the What if? path, it is still worth asking what went so awry with the Turkish courtsmartial in 1919 and the subsequent British abdication of responsibility when they abandoned trials in Malta; what went wrong with the domestic Leipzig trials after World War I; what have been the effects of the thousands of trials in East and West Germany and in Austria since World War II; and what can and should be said of the three aborted war-crimes trials in Australia in the 1980s. Can trials be educative and not simply punitive? In the face of immense denialism and evasion of culpability, 
trials in a public arena, and those that produce indelible records, have incalculable value in documenting that "something happened."

Elazar Barkan has dealt with the guilt of nations, and Roy Brooks has assembled a consensus among victims that "sorry isn't enough." 55 Why is it that nations are sometimes willing to intervene in humanitarian or military modes, to prosecute or deport perpetrators, to make apologies for the "problem from hell," but refuse to entertain the idea of making even miserable reparations? Democratic Australia is a case in point. In 1992, Labor Prime Minister Paul Keating admitted the murders of Aborigines, the dispossessions, the diseases, the removal of children, the smashing of traditional life, and their exclusion from society and its benefits. This was one kind of balm for the victim people. John Howard's Conservative government (1996-2007), however, saw this moral inculpation as a slide toward costly economic reparations, and refused any admission or apology for exactly that reason. Kevin Rudd's Labor government apologized in 2008, with some reluctant bipartisan support, but everyone was happy enough that the rider to the apology was that there would be no reparations. Ironically, the Australian state said to have been the most murderous in the nineteenth century, Tasmania, is the only one to have initiated financial restitution. In November 2006, the Tasmanian Parliament passed the Stolen Generations of Aboriginal Children Act. In January 2008, Tasmania's premier, Paul Lennon, declared that the lives of 106 claimants had been "deeply affected by this flawed policy of [forcible child] separation." 56 Of these, 84 were paid approximately US $\$ 54,000$ each, and each family of a deceased claimant received approximately US $\$ 4,600$. Germany's Forced Labor Compensation Program, set up tardily in 2000, paid out to each of 1.7 million survivors sums ranging from US $\$ 3,000$ to US\$9,900. Such mindsets and value systems are more than ready for examination.

Genocide remains undiminished in human affairs. The study of genocide is clearly an unfinished project. Controversies will continue, and many unanswered questions may well be resolved. The cleavages discussed are real, but they are soluble, certainly not fatal to collegiality or intellectual inquiry. Above all, we are on the same side, and we pursue these ventures into the continuum of death and destruction with a high degree of moral dignity.

\section{Notes}

1. Brewton Berry, Race Relations: The Interaction of Ethnic and Racial Groups (Boston: Houghton Mifflin, 1951).

2. David Szonyi, ed., The Holocaust: An Annotated Bibliography and Resource Guide (New York: Ktav, 1985).

3. Leo Kuper, Genocide: Its Political Use in the Twentieth Century (London: Penguin, 1981).

4. Yvan van Garsse, A Bibliography of Genocide, Crimes Against Humanity and War Crimes (Sint Niklaas Waas, Belgium: Studiecentrum voor Kriminologie en Gerechtelyke Geneeskunde, 1970).

5. Richard Hovannisian, ed., The Armenian Holocaust: A Bibliography Relating to the Deportations, Massacres, and Dispersion of the Armenian People, 1915-1923 (Cambridge, MA: Armenian Heritage Press, 1980); Israel W. Charny, ed., Genocide: A Critical Bibliographic Review, vol. 1-4 (London: Mansell/New Brunswick, NJ: Transaction, 1988-2003); Samuel Totten, ed., Genocide: A Critical Bibliographic Review, vol. 5-9 (New Brunswick, NJ: Transaction, 2005-2012).

6. Yehuda Bauer, Rethinking the Holocaust (New Haven, CT: Yale University Press, 2001).

7. Ben Kiernan, Blood and Soil: A World History of Genocide and Extermination from Sparta to Darfur (New Haven, CT: Yale University Press, 2007). 
8. Norman Naimark, Fires of Hatred: Ethnic Cleansing in Twentieth-Century Europe (Cambridge, MA: Harvard University Press, 2001), 3-4.

9. J. Castell Hopkins, The Sword of Islam, or Suffering Armenia (Brantford, ON: BradleyGarretson, 1896), 313; Marion Harland, Under the Flag of the Orient: The Thrilling Story of Armenia (Philadelphia: Historical Publishing, 1897), 415. On 19 May 1896, the Sydney Morning Herald reported that "a fearful holocaust was executed locally" by Turkish officials.

10. See István Deák, "The Incomprehensible Holocaust," New York Review of Books 36, no. 14 (28 September 1989), http://www.nybooks.com/articles/archives/1989/sep/28/theincomprehensible-holocaust/ (accessed 5 October 2011).

11. Arno Mayer, Why Did the Heavens Not Darken? The "Final Solution" in History (New York: Pantheon, 1988).

12. Convention on the Prevention and Punishment of the Crime of Genocide, 9 December 1948, 78 U.N.T.S. 277, http://www2.ohchr.org/english/law/genocide.htm (accessed 5 October 2011).

13. Frank Chalk and Kurt Jonassohn, The History and Sociology of Genocide: Analyses and Case Studies (New Haven, CT: Yale University Press, 1990).

14. Helen Fein, Genocide: A Sociological Perspective (London: Sage, 1993), 28-31.

15. Mark Levene, Genocide in the Age of the Nation-State, vol. 2, The Rise of the West and the Coming of Genocide (London: I.B. Tauris, 2005).

16. Barbara Harff and Ted Gurr, "Towards Empirical Theory of Genocides and Politicides: Identification and Measurement of Cases since 1945," International Studies Quarterly 32 (1988): 359-71.

17. William Rubinstein, "Towards an Historical Typology of Genocide," Australian Journal of Jewish Studies 16 (2002): 152-58.

18. See Ward Churchill, A Little Matter of Genocide: Holocaust and Denial in the Americas, 1492 to the Present (San Francisco: City Lights, 1997), 431-37.

19. Yehuda Bauer, lectures at Yad Vashem, Jerusalem; R. Hrair Dekmejian, "Determinants of Genocide: Armenians and Jews as Case Studies," in The Armenian Genocide in Perspective, ed. Richard Hovannisian (New Brunswick, NJ: Transaction, 1980).

20. Adam Jones, ed., Genocide, War Crimes and the West: History and Complicity (London: Zed Books, 2004).

21. Samuel Totten and Robert Hitchcock, eds., Genocide of Indigenous Peoples: A Critical Bibliographic Review, vol. 8 (New Brunswick, NJ: Transaction, 2011).

22. Samantha Power, "A Problem from Hell": America and the Age of Genocide (New York: Basic Books, 2002).

23. Churchill, A Little Matter of Genocide.

24. Colin Tatz, With Intent to Destroy: Reflecting on Genocide (London: Verso, 2003).

25. See Margaret Jacobs, White Mother to a Dark Race: Settler Colonialism, Maternalism and the Removal of Indigenous Children in the American West and Australia, 1880-1940 (Lincoln: University of Nebraska Press, 2009).

26. Tatz, With Intent to Destroy, 98-99.

27. Matthew Storey, "Kruger v the Commonwealth: Does genocide require malice?," University of New South Wales Law Journal 21, no. 1 (1998): 224-31.

28. Raimond Gaita, "Genocide: The Holocaust and the Aborigines," Quadrant 16, no. 11 (1997): 21.

29. Kurt Jonassohn, "Hunger as a Low Technology Weapon, with Special Reference to Genocide," in Genocide Perspectives I: Essays in Comparative Genocide, ed. Colin Tatz, 263-88 (Sydney: Centre for Comparative Genocide Studies, Macquarie University, 1997); David Marcus, "Famine Crime in International Law," American Journal of International Law 97, no. 2 (2003): 245-81.

30. James Mace, "Soviet Man-Made Famine in Ukraine," in Century of Genocide: Eyewitness Accounts and Critical Views, ed. Samuel Totten, William Parsons, and Israel Charny (New York: Garland, 1997), 78-112; Robert Conquest, The Harvest of Sorrow: Soviet 
Collectivisation and the Terror-Famine (Edmonton: University of Alberta Press, 1986); Stephen Wheatcroft, ed., Challenging Traditional Views of Russian History (London: Palgrave, 2002).

31. Cormac Ó'Gráda, Black '47 and Beyond: The Great Irish Famine in History, Economy and Memory (Princeton, NJ: Princeton University Press, 1999); James Donnelly, The Great Irish Potato Famine (London: History Press, 2008).

32. Paul Bartrop, ed., False Havens: The British Empire and the Holocaust (Lanham, MD: University Press of America, 1995), 64-65.

33. Allen Wells, Tropical Zion: Trujillo, FDR and the Jews of Sosúa (Durham, NC: Duke University Press, 2009).

34. See Michael Neufeld and Michael Berenbaum, eds., The Bombing of Auschwitz: Should the Allies Have Attempted It? (New York: St Martin's, 2000).

35. Martin Gilbert, Auschwitz and the Allies: A Devastating Account of How the Allies Responded to the News of Hitler's Mass Murder (London: Owl Book, 1981).

36. Paul O'Shea, A Cross Too Heavy: Eugenio Pacelli: Politics and the Jews 1917-1943 (Sydney: Rosenberg, 2008).

37. Andrew Denton, interview with Bill Clinton, Enough Rope (19 July 2004), Australian Broadcasting Corporation, http://www.abc.net.au/tv/enoughrope/transcripts/s1157592.htm (accessed 17 October 2011).

38. Saul Friedländer, "Some Aspects of the Historical Significance of the Holocaust," Jerusalem Quarterly 1 (1976): 36-59.

39. Robert Wistrich, A Lethal Obsession: Anti-Semitism from Antiquity to the Global Jihad (New York: Random House, 2010).

40. Henry Reynolds, An Indelible Stain? The Question of Genocide in Australia's History (Melbourne: Penguin, 2001).

41. Raphael Lemkin, “Tasmania," Patterns of Prejudice 39, no. 2 (2005): 170-96.

42. Tatz, With Intent to Destroy, ch. 4.

43. Raphael Lemkin, Axis Rule in Occupied Europe: Laws of Occupation, Analysis of Government, and Proposals for Redress (Washington, DC: Carnegie Foundation for International Peace, 1944), 79.

44. See William Schabas, Genocide in International Law: The Crime of Crimes (Cambridge: Cambridge University Press, 2009), 185-87.

45. "Descendants of Turkey's Genocide Victims File Lawsuit against Turkey Seeking \$65 Million in Seized Land," Massis Post: Mass Weekly Online, 16 December 2010.

46. The draft report, prepared by Dr. Alfred de Zayas, Dr. Jermaine McCalpin, former ambassador Ara Papian, and Dr. Henry Theriault, was discussed at a forum held at the University of California-Los Angeles in October 2010.

47. Walter Rindele and Bernard Norling, The Nazi Impact on a German Village (Lexington: University Press of Kentucky, 1993); Eric Johnson and Karl-Heinz Reuband, What We Knew: Terror, Mass Murder and Everyday Life in Nazi Germany (London: John Murray, 2005).

48. Daniel Jonah Goldhagen, Hitler's Willing Executioners: Ordinary Germans and the Holocaust (New York: Knopf, 1996).

49. Peter Fritzsche, Life and Death in the Third Reich (London: Belknap / Harvard University Press, 2008).

50. Raul Hilberg, The Destruction of European Jews, 3rd ed. (New Haven, CT: Yale University Press, 2003).

51. Christopher Browning, Ordinary Men: Reserve Police Battalion 101 and the Final Solution in Poland (New York: HarperCollins, 1992).

52. James Waller, Becoming Evil: How Ordinary People Commit Genocide and Mass Killing (Oxford: Oxford University Press, 2002), 279.

53. Ibid., 271. 
54. Keith Watenpaugh, "The League of Nations' Rescue of Armenian Genocide Survivors and the Making of Modern Humanitarianism, 1920-27," American Historical Review 115, no. 5 (2010): 1315-39.

55. Elazar Barkan, The Guilt of Nations: Restitution and Negotiating Historical Injustices (New York: Norton, 2000). Roy Brooks, ed., When Sorry Isn't Enough: The Controversy over Apologies and Reparations for Human Injustice (New York: New York University Press, 1999).

56. Paul Lennon, "Cash is a Mere Gesture," The Australian, 29 January 2008, 12. 